\title{
HUBUNGAN ANTARA POWER TUNGKAI, KOORDINASI MATA-TANGAN, DAN RASA PERCAYA DIRI DENGAN HASIL KEMAMPUAN LAY-UP SHOOT BOLA BASKET
}

\author{
Mimi Haetami \\ Pendidikan Jasmani, FKIP Universitas Tanjungpura \\ mh.albantani@gmail.com
}

\begin{abstract}
Abstact
The purpose of this study, to find out how much the relationship between power limbs, eye-hand coordination, and a sense of confidence with the results of the ability to shoot shoots on basketball.This research method uses a correlation method with product moment calculation techniques. The sample amounted to 20 people from all extra-basketball players / athletes in SMK Negeri 4 Kota Pontianak.The calculation results obtained show; 1). There is a positive relationship between Leg Power (XI) with the results of Lay-up Shoot (Y) skills of 68\%. 2). There is a positive relationship between hand eye coordination (X2), with the results of Lay-up Shoot skills $(Y)$ of $42.2 \% .3)$ There is a positive relationship between self-confidence (X3) and the results of Lay-up Shoot $(Y)$ skills of $47.5 \%$.Thus there is a positive relationship between power limbs (X1) eye-hand coordination (X2) and self-confidence (X3) together towards the results of the Lay-up Shoot skill $(Y)$ obtained from the R correlation coefficient of $81.8 \%$. So the conclusions from this study show that power limbs, eye-hand coordination, and self-confidence have a significant relationship with the results of basketball shoot lay-up capabilities.
\end{abstract}

Keywords: Lay-up, Leg Power, Hand Eye Coordination, Confidence

\section{PENDAHULUAN}

Keterampilan berolahraga pada setiap orang tidak sendirinya dibawa sejak lahir. Manusia secara genetik bisa saja lebih kuat, lebih tinggi, dan lebih cepat. Akan tetapi kualitas fisik seseorang tidak secara langsung berdampak kepada kemampuan keterampilan olahraga. Oleh karena itu, belajar, berlatih, secara terencana dan sistematis mutlak harus dilakukan oleh setiap orang. Peran guru pendidikan jasmani maupun pelatih dalam melakukan pembelajaran dan latihan sanagat determinan dalam keberhasilannya.

Dalam pendidikan formal, khususnya dari Sekolah Dasar sampai Sekolah Menengah Atas, keberadaan pendidikan jasmani merupakan keniscayaan. Karena pendidikan jasmani merupakan bagian integral yang tidak terpisahkan dari pendidikan secara keseluruhan. Ini artinya bahwa pendidikan jasmani memberikan kontribusi yang sangat berarti dengan pertumbuhan dan perkembangan hidup manusia. Hal ini senada dengan yang dikemukakan Pangrazi dan Dauer sebagai berikut,

"Physical education is a part of the general education program, that contributes, primarily through movement experiences, to the total growth and development of all children. Physical education is defined as education of and through movement, and must be conducted in a menner that merits this meaning". ${ }^{1}$

Sehingga diperlukan pembinaan pendidikan jasmani secara benar dan berkesinambungan baik dilingkungan sekolah maupun dimasyarakat. Pembinaan pendidikan jasmani dan olahraga disekolah dapat diartikan sebagai upaya untuk memupuk bakat dan minat siswa dilingkungan sekolah, dengan harapan agar siswa dapat meningkatkan kemampuan secara optimal. Karena itu peran pendidikan jasmani dilingkungan sekolah perlu ditingkatkan.

\footnotetext{
${ }^{1}$ Pangrazi \& Dauer. Dynamic physical education for elementary school, 2nd Ed., Brown \& Benchmark Publishers Dubugue Iowa, 1992.
} 
Pelaksanaan pendidikan jasmani disekolah negeri maupun swasta dilaksanakan berdasarkan kurikulum yang berlaku, yang dalam implementasinya di lapangan dijumpai banyak kendala. Salah satu kendala yang nampak adalah terbatasnya jam pelajaran pendidikan jasmani. Karena itu diperlukan kegiatan ektrakulikuler di luar jadwal pelajaran. Beberapa jenis olahraga yang diajarkan di sekolah meliputi kegiatan pokok yang terdiri atas :olahraga permainan, senam, atletik, aquatik dan lain-lain. Pada tingkat sekolah menengah atas pokok bahasan olahraga permainan terdapat permainan bola basket, tak terkecuali di SMK Negeri 4 Kota Pontianak .Adapun prestasi bola basket yang diraih siswa SMK Negeri 4 Kota Pontianak sampai tahun 2014 kurang maksimal, hal tersebut dapat terlihat dari raihan prestasi bola basket belum pernah menjuarai pertandingan-pertandingan baik ditingkat kota, provinsi maupun nasional. Ada beberapa permasalahan penyebab kurang maksimalnya prestasi bola basket SMK Negeri 4 Kota Pontianak. Permasalahan pertama adalah kurangnya jumlah latihan dalam 1 minggu hanya satu kali latihan, dikarenakan keterbatasan waktu dan tempat latihan, sehingga siswa yang mengikuti ektrakulikuler bola basket menjadi kurang maksimal. Permasalahan kedua adalah para siswa belum maksimal dalam penguasaan teknik dasar bola basket diantaranya yaitu teknik dasar tembakan lay-up shoot. Siswa yang lompatannya rendah rata-rata gagal dalam melakukan tembakan layup shoot. Sedangkan siswa yang lompatannya tinggi rata-rata berhasil melakukan tembakan lay-up shoot.

Menurut Nuril Ahmad, permainan bola basket merupakan cabang olahraga yang di dalamnya ada beberapa teknik dasar yaitu : (1) Operan (passing), (2) menangkap (catching), (3) menembak (shooting), (4) menggiring (dribble), (5) olah kaki (foot work), (6) memutar badan dengan tumpuan salah satu kaki (Pivot), dan (7) gerak tipu (fakes and feints). ${ }^{2}$ Sedangkan definisi menembak (shooting) menurut Nuril Ahmad adalah usaha memasukan

${ }^{2}$ Nuril Ahmad. Permainan Bola Basket.(Surakarta : Era Intermedia. 2007), h.19 bola kekeranjang, dapat dilakukan dengan satu tangan, dua tangan, dan lay-up shoot".

Definisi tembakan lay-up shoot adalah tembakan yang dilakukan dengan jarak dekat sekali dengan keranjang basket, hingga seolaholah bola itu diletakan kedalam keranjang basket yang di dahului dengan gerakan dua langkah". 4

Berdasarkan pendapat di atas, power otot tungkai sangat diperlukan dalam melakukan langkah-langkah gerakan tembakan lay-up shoot bola basket. Selain menggunakan power otot tungkai gerakan tembakan lay-up shoot juga menggunakan mata untuk melihat ring basket dan tangan untuk memasukan bola kedalam ring basket. Oleh karena itu koordinasi mata dan tangan juga berperan dalam gerakan tembakan lay-up shoot.

Definisi koordinasi adalah prilaku dua atau lebih dari komponen kondisi fisik yang satu sama lainnya saling berkaitan untuk menghasilkan suatu keterampilan gerak". ${ }^{5}$

Selain hal-hal di atas, masih ada yang perlu diperhatikan dalam keberhasilan melakukan gerakan tembakan lay-up shoot bola basket, yaitu tentang rasa percaya diri, yang merupakan sebuah keyakinan diri yang seseorang pada saat melakukan gerakan. Rasa percaya diri sangat mempengaruhi dalam pencapaian hasil belajar suatu cabang olahraga. Menurut Mathews bahwa rasa percaya diri adalah kemampuan untuk mencapai keberhasilan. ${ }^{6}$

Pendapat lain dikemukakan Winkel. W.S. bahwa rasa percaya diri adalah keyakinan akan kemampuan diri sendiri sehingga tidak terpengaruhi oleh orang lain dan mampu mengetahui apa yang mampu dilakukan untuk mengambil keputusan sesuai dengan harapan. ${ }^{7}$ Sebagai upaya untuk mengetahui seberapa

\footnotetext{
${ }^{3}$ Ibid, h.20

${ }^{4}$ Kosasih.Fundamental Basketball (2008), h 51

${ }^{5}$ Schmidt, Ricard A, Motor Learning and

Performance(Champaign: Human Kinetics

Publishers Inc)

${ }^{6}$ Mathews K Donalk, Measurementin Physical

Education. (London, Philedephia : Sauders

Company, 1985), h.58

${ }^{7}$ Winkel .W.S. Psikologi Pengajaran.(Bandung : PT.

Gramedia, 1989), h.90
} 
hubungan dari hal-hal tersebut di atas, diperlukan suatu penelitian yang akan dilaksanakan di SMK Negeri 4 Kota Pontianak.

Berdasarkan latar belakang yang telah dikemukakan di atas, maka penelitian ini mengambil judul "Hubungan antara power tungkai, koordinasi mata-tangan dan rasa percaya diri dengan keterampilan tembakan layup shoot dalam permainan bola basket".

Keterampilan lay-up shoot merupakan kemampuan seseorang melakukan tembakan jarak dekat dibawah atau dibibir keranjang basket, yang didahului dengan dua irama langkah (two count ritm). Hal ini senada dengan pendapat Nuril Ahmadi bahwa: "tembakan yang dilakukan dengan jarak dekat sekali dengan keranjang basket, hingga seolah-olah bola itu diletakan ke dalam keranjang basket yang didahului dengan gerak dua langkah" 8

Pendapat lain yang dikemukakan Ibrahim Amir Hasan, "lay-up shoot adalah gerakan menembakan bola pada keranjang dalam jarak dekat dan merupakan jenis tembakan yang gerakannya seperti menaruh bola langsung pada keranjang dengan tujuan untuk mempermudah permainan bola basket dalam mencetak angka" 9

Rangkaian melakukan tembakan lay-up shoot sebagaimana dikemukakan Soebagio Hartoko sebagai berikut: (1) Pemain mendribble bola kearah ring, (2) Setelah jarak cukup dekat dengan ring, bola dipegang dengan kedua tangan, (3) Apabila pemain melakukan lay-up shoot dengan tangan kanan, kaki kiri yang menjadi tumpuan untuk menembakan bola, begitu pula sebaliknya, (4) Pemain menghitung langkah yang pemain buat, selanjutnya pemain melompat setinggitingginya dan menaruh bola pada ring, (5) Dalam memasukan bola dapat langsung ditaruh pada ring atau dapat juga dengan memantulkannya terlebih dahulu pada papan ring, (6) Pemain mengatur tenaga dalam melepaskan bola sehingga bola dapat masuk pada ring, (7) Pemain sebaiknya memvariasikan latihan ini dengan tangan dan langkah pemain, (8) Pemain sebaiknya melakukan latihan ini

\footnotetext{
${ }^{8}$ Nuril Ahmad, Permainan Bola Basket, (Surakarta : Era Intermedia. 2007), h.19

${ }_{9}^{9}$ Ibraham Amir Hasan, Indonesian Streetball, (Bandung : PT Mizan Pustaka. 2008), h 79
}

dengan kecepatan dalam melakukan lay-up shoot, (9) Pemain sebaiknyamelakukan latihan ini hingga pemain mahir. ${ }^{10}$

Power merupakan salah satu komponen biomotorik yang memiliki peranan yang besar, untuk meningkatkan prestasi olahraga dan sangat diperlukan dalam berbagai cabang olahraga. Seorang atlet yang ingin berprestasi harus memiliki power yang baik. Power disebut sebagai power explosive, yang berkaitan dengan kekuatan dan kecepatan kontraksi otot dinamik dan eksplosif secara maksimal dalam durasi waktu yang singkat.

Kekuatan dan kecepatan merupakan dua komponen kondisi fisik yang dipadukan secara bersama-sama, sehingga akan menghasilkan power yang merupakan keterampilan dari otot atau sekelompok otot untuk mengatasi beban tahanan dengan kecepatan tinggi dalam satu gerakan utuh dengan waktu yang singkat. Pada prinsipnya power digunakan dalam suatu gerakan dengan mengarahkan tenaga secara maksimal dalam waktu yang cepat. Seperti yang dikemukakan M. Sajoto bahwa "Power atau muscular adalah keterampilan seseorang untuk melakukan kekuatan maksimal dengan usaha yang dikerahkan dalam waktu yang sesingkat-singkatnya". ${ }^{11}$ Sedangkan menurut Harsono power adalah "keterampilan otot untuk mengerahkan kekuatan maksimal dalam waktu yang sangat cepat". ${ }^{12}$ Pendapat lain dikemukakan Mulyono B. bahwa "Power adalah keterampilan untuk mengerahkan kekuatan maksimum dalam jangka waktu yang minim". ${ }^{13}$

Suharno HP. Mengartikan power sebagai keterampilan otot atau sekelompok otot dalam mengatasi tahanan beban dengan kecepatan tinggi dalam satu gerakan yang utuh, yang dilakukan secara eksplosif dengan memadukan

\footnotetext{
${ }^{10}$ Soebagio Hartoko, Teori dan Praktek Bola Basket I, (Surakarta : FKIP UNS. 1994), h.21

${ }^{11}$ M. Sajoto, Pembinaan Kondisi Fisik Dalam Olahraga.(Semarang : Dahara Prize 1995), h.58

${ }^{12}$ Harsono.Coaching danAspek Psikologisdalam Coaching.(Jakarta : CV Tambak Kusuma 1988), h. 88

${ }^{13}$ Mulyono B. TesdanPengukurandalamPendidikan Jasmani.(Surakarta : UNS Press 2001), h.58
} 
antara kekuatan dan kontraksi otot. ${ }^{14}$ Menurut M. Sajoto Power otot atau muscular power adalah keterampilan seseorang untuk melakukan kekuatan maksimum, dengan usahanya yang dkerjakan dalam waktu sependek-pendeknya. Dalam hal ini telah dinyatakan bahwa power otot merupakan hasil perkalian antara kekuatan dan kecepatan. ${ }^{15}$ Menurut Bompa dan Groppel menyatakan power adalah kombinasi dari kekuatan dan kecepatan gerak. ${ }^{16}$ Power adalah keterampilan otot atau sekelompok otot dalam melakukan kerja secara eksplosif.

Definisi koordinasi menurut Schmidt, Ricard A "koordinasi adalah prilaku dua atau lebih dari komponen kondisi fisik yang satu sama lainnya saling berkaitan untuk menghasilkan suatu keterampilan gerak". ${ }^{17}$ Sedangkan menurut Ismaryati mendefinisikan koordinasi adalah hubungan yang harmonis dari hubungan saling pengaruh diantara kelompokkelompok otot selama melakukan kerja, yang ditunjukan dengan berbagai tingkat keterampilan". ${ }^{18}$ Ahli lain memberikanbatasan mengenai koordinasi yaitu; "keterampilan untuk memadukan berbagai macam gerakan kedalam satu atau lebih pola gerak khusus". ${ }^{19}$

Sedangkan menurut Harsono berpendapat bahwa keterampilan koordinasi gerak mutlak diperlukan dalam kegiatan olahraga, tanpa memiliki koordinasi gerak yang baik maka akan sulit untuk menampilkan keterampilannya. Dalam koordinasi termasuk juga agilitas, balance (keseimbangan), dan kinestetik sence". ${ }^{20}$

\footnotetext{
${ }^{14}$ Suharno.Metodologi Pelatihan. (Yogyakarta : IKIP Yogyakarta Press 1993), h.33

${ }^{15}$ M. Sajoto, Op cit, h.17

${ }^{16}$ Bompa O Tudor, Theory and Methodology of

Training The Key to Athletic Performance.

(Department of Physical Education York University

Canada 1990), h.273

${ }^{17}$ Schmidt, Ricard A, Motor

LearningandPerformance,(Champaign : Human

Kinetics Publishers Inc. 1988), h.265

${ }^{18}$ Ismaryati, Tesdan Pengukuran Olahraga,

(Surakarta : Sebelas Maret University Press 2006), h.53

${ }^{19}$ Barrow dan Mc Gee, Op.cit, h.220

${ }^{20}$ Harsono, Op cit, h.219
}

Harsono, "tingkat koordinasi atau baik tidaknya koordinasi gerak seseorang tercermin dalam keterampilannya untuk melakukan suatu gerakan secara mulus, tepat (precise). ${ }^{21}$ Menurut Kusmaedi, "koordinasi merupakan keterampilan untuk melakukan gerakan atau kerja dengan tepat dan efisien. ${ }^{22}$

Berdasarkan pendapat di atas, jelas bahwa rumusan koordinasi merupakan salah satu unsur yang penting untuk keterampilan gerak motorik termasuk gerakan tembakan lay-up shoot. Tingkat koordinasi atau baik tidaknya koordinasi gerak seseorang tercermin dalam keterampilannya melakukan suatu keterampilan secara sempurna, akan tetapi juga mudah dan cepat dapat melakukan suatu gerakan secara mulus, tepat dan efisien.

Seorang siswa dengan koordinasi yang baik bukan hanya mampu melakukan suatu keterampilan secara sempurna, akan tetapi juga mudah dan cepat dalam melakukan atau menyelesaikan suatu tugas latihan.

Ada beberapa faktor yang menjadi penentu dalam koordinasi yang baik, yaitu; (1) pengaturan saraf pusat dan saraf tepi, hal ini berdasarkan pembawaan siswa dan hasil latihan-latihan. (2) baik dan tidaknya keseimbangan, kelincahan dan kelentukan siswa. (4) baik dan tidaknya koordinasi kerja saraf, otot dan indera". ${ }^{23}$

Dalam melakukan gerakan tembakan layup shoot dalam permainan bola basket, koordinasi gerak yang dibutuhkan merupakan perpaduan antara keterampilan melihat bola saat di dribble, melangkah untuk awalan, melompat, melihat sasaran (ring) dan memasukan bola ke ring. Maka dari itu bagi siswa yang memiliki tingkat koordinasi yang baik akan mampu dan tidak hanya menampilkan keterampilan yang baik, tetapi juga akan cepat menyelesaikan tugas latihan.

Dengan demikian kesimpulan dari pendapat-pendapat tersebut diatas ialah koordinasi merupakan keterampilan dari dua atau lebih organ tubuh yang bergerak dengan suatu olah gerakan tertentu dan sangat

\footnotetext{
${ }^{21}$ Harsono, Op cit, h.220

${ }^{22}$ Kusmaedi, Op cit,h.83

${ }^{23}$ Suharno, H.P. Op.cit,h.62
} 
dibutuhkan dalam melakukan gerakan tembakan lay-up shoot bola basket.

Rasa percaya diri merupakan sebuah keyakinan diri pada seseorang yang dirasakan dan dilaksanakan, rasa percaya diri sangat mempengaruhi dalam pencapaian hasil belajar suatu cabang olahraga. Menurut Mathews bahwa rasa percaya diri adalah keterampilan untuk mencapai keberhasilan. ${ }^{24}$

Rasa pecaya diri erat hubungannya dengan kondisi emosional seseorang dengan rasa percaya diri akan terbentuk rasa nyaman hal ini terlihat dari tingkah laku seorang anak didik yang tampak lebih rileks dalam menghadapi sesuatu dan tidak mudah ragu dan bimbang.

Veducci, frank menjelaskan bahwa rasa percaya diri memberikan dampak yang positif dalam hal sebagai berikut : (a) Emosi, kala seseorang memiliki rasa percaya diri yang tinggi akan lebih mudah dalam suatu keadaan yang menekan dan ia dapat menguasai dirinya untuk bertindak dan dapat menentukan saat yang tepat dalam melakukan tindakan. (b) Konsentrasi, dengan memiliki rasa percaya diri yang tinggi, seseorang akan lebih mudah dalam memusatkan perhatiannya pada hal-hal yang menghawatirkan. (c) Sasaran, dengan rasa percaya diri yang tinggi seseorang akan memiliki kecenderungan untuk mengarahkan tindakan yang lebih terfokus sehingga dalam mencapai target lebih mudah. (d) Usaha, seseorang dengan percaya diri tinggi tidak mudah putus asa dan prustasi dalam menghadapi masalah dan dia akan berusaha lebih baik. (e) Strategi, dengan percaya diri tinggi cenderung terus akan mengembangkan strategi untuk mencapai target. (f) Momentum, dengan percaya diri yang tinggi seseorang akan lebih tenang, ulet, dan tidak mudah patah semangat. ${ }^{25}$

Setiap individu memiliki target percaya diri yang berbeda-beda ada yang terlalu percaya diri ada yang kurang percaya diri, dalam beberapa hal sesuatu yang kurang percaya diri secara psikologis menurunkan efektivitas

\footnotetext{
${ }^{24}$ Mathews K Donalk, Measurementin Phcicak Education. (London : Sauders company 1985), h.58

${ }^{25}$ Veducci, Frank, Measurement Concept on Physical Education (St Louis : The C.V.Most By Company, 1980), h.67
}

gerakan selain ia melakukan gerakan yang ditampilkan. Selanjutnya kurang percaya diri menimbulkan keragu-raguan dalam mengambil keputusan sehingga seorang anak didik tidak bias mengeluarkan keterampilannya secara maksimal.

Menurut Winkel. W.S. bahwa rasa percaya diri adalah keyakinan akan keterampilan diri sendiri sehingga tidak terpengaruh oleh orang lain dan mampu mengetahui apa yang mampu dilakukan untuk mengambil keputusan sesuai dengan harapan. ${ }^{26} \mathrm{Jadi}$ dari pendapat di atas berdasarkan pada hasil-hasil penelitian menyatakan bahwa meningkatkan rasa percaya diri dapat meningkatkan akan terbentuk rasa nyaman hal ini terlihat dari tingkah laku seorang anak didik yang tampak lebih rileks dalam menghadapi sesuatu dan tidak mudah ragu dan bimbang. Jadi pada saat melakukan lay-up shoot harus didukung oleh rasa percaya diri yang baik sehingga menimbulkan keyakinan untuk dapat malakukan lay-up shoot denganbaik. Rasa percaya diri mampu membangkitkan motivasi tinggi yang dengan penyelesaian tugas gerak yang dilakukan secara sempurna.

\section{METODE}

Metode penelitian yang digunakan dalam penelitian ini adalah metode diskriptif dengan studi korelasional, dengan menggunakan analisis regresi ganda bertujuan untuk mengetahui ada tidaknya hubungan power otot tungkai, koordinasi mata tangan dan rasa percaya diri dengan keterampilan tembakanlayup shoot. Serta menjelaskan hubungan setiap variabel bebas dengan variabel terikat baik secara tersendiri-sendiri maupun bersama-sama, adapun pola hubungan antar variabel bebas dengan terikat dapat digambarkan dalam konstelasi gambar 1 :

\footnotetext{
${ }^{26}$ Winkel .W.S. Op.cit, h.90
} 


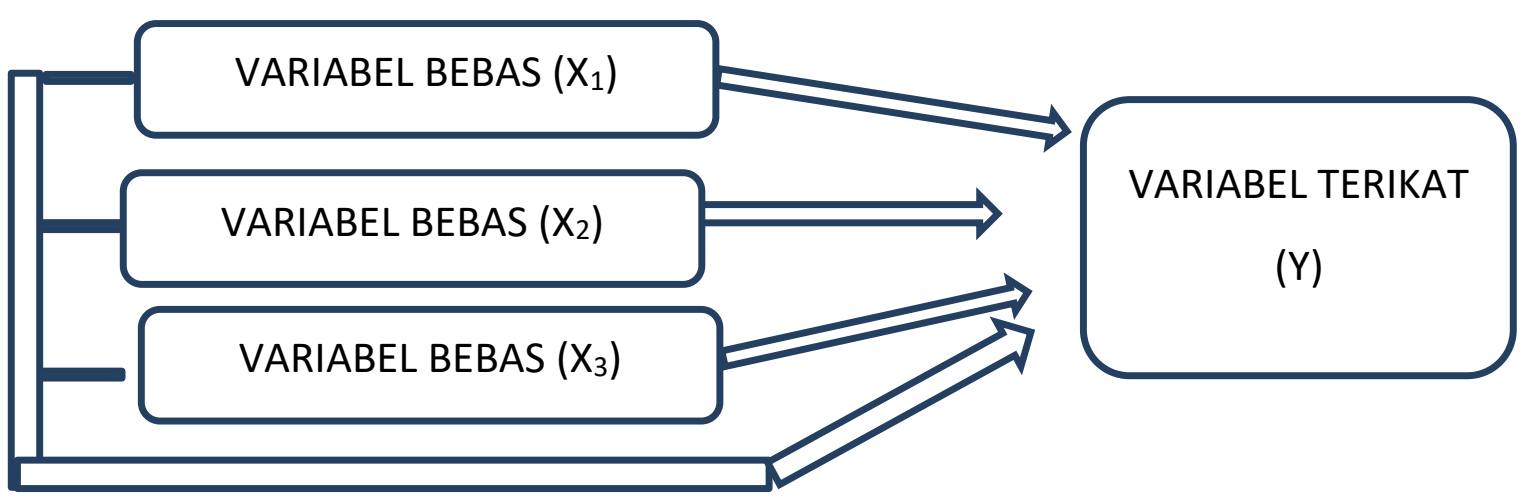

Gambar 1. Pola Hubungan Variabel Penelitian

Keterangan :

$\mathrm{X}_{1} \quad$ :Power Otot Tungkai

$\mathrm{X}_{2}$ : Koordinasi Mata Tangan

$\mathrm{X}_{3} \quad$ : Rasa Percaya Diri

Y : Keterampilan Tembakan lay-up shootBola Basket

\section{HASIL DAN PEMBAHASAN}

Dari hasil Pengujian Hipotesis Power

Tungkai $\left(\mathrm{X}_{1}\right)$, Koordinasi Mata-tangan $\left(\mathrm{X}_{2}\right)$, dan Rasa Percaya Diri $\left(\mathrm{X}_{3}\right)$ Dengan Hasil Keterampilan Lay-up Shoot bola basket (Y), maka didapat:

Dengan melakukan analisis regresi linier sederhana dengan bantuan SPSS 17.0 for windows dapat dilihat bahwa nilai koefisien korelasi $(\mathrm{R})=0,909$ yang berarti hubungan variabel power tungkai $\left(\mathrm{X}_{1}\right)$, koordinasi mata tangan $\left(\mathrm{X}_{2}\right)$, dan rasa percaya diri $\left(\mathrm{X}_{3}\right)$ dengan variabel hasil keterampilan Lay-up Shoot bola basket (Y) positif hubungannya hampir sempurna. Lebih jelasnya dapat dilihat pada table 1 sebagai berikut:

Tabel 1

Nilai Koefesien Korelasi (R) dan Koefisien Determinasi (R Square) dari

Variabel Power Tungkai $\left(\mathbf{X}_{1}\right)$, Koordinasi Mata-tangan $\left(\mathbf{X}_{2}\right)$, dan Rasa Percaya Diri $\left(\mathbf{X}_{3}\right)$ Dengan Variabel Hasil Keterampilan Lay-up Shoot bola basket (Y) Model Summary ${ }^{b}$

\begin{tabular}{lrrrr}
\hline Model & R & R Square & $\begin{array}{c}\text { Adjusted R } \\
\text { Square }\end{array}$ & \multicolumn{2}{c}{$\begin{array}{c}\text { Std. Error of the } \\
\text { Estimate }\end{array}$} \\
\hline 1 & $.904^{\mathrm{a}}$ & .818 & .784 & 4.62567 \\
\hline
\end{tabular}

a. Predictors: (Constant), X3, X2, X1

b. Dependent Variable: Y

Koefisien determinasi atau $\mathrm{R}$ Square sebesar 0,818 adalah pengkuadratan dari koefisien korelasi. Hal ini menunjukkan $81,8 \%$ variabel hasil keterampilan Lay-up Shoot bola basket (Y) ditentukan oleh faktor variabel Power
Tungkai $\left(\mathrm{X}_{1}\right)$, Koordinasi Mata-tangan $\left(\mathrm{X}_{2}\right)$, dan rasa percaya diri $\left(\mathrm{X}_{3}\right)$ sedangkan sisanya $18.2 \%$ ditentukan faktor-faktor lain.

Uji $t$ dilakukan untuk menguji signifikansi regresi variabel power tungkai $\left(\mathrm{X}_{1}\right)$, 
koordinasi mata-tangan $\left(\mathrm{X}_{2}\right)$, dan rasa percaya diri $\left(\mathrm{X}_{3}\right)$ terhadap variable hasil keterampilan Lay-up Shoot bola basket (Y). Keputusan yang diambil adalah sebagai berikut :

1) $\mathrm{H}_{0}=0$; atau koefisien regresi variabel power tungkai $\left(\mathrm{X}_{1}\right)$, koordinasi mata-tangan $\left(\mathrm{X}_{2}\right)$, dan rasa percaya diri $\left(\mathrm{X}_{3}\right)$ tidak signifikan terhadap variabel hasil keterampilan Lay-up Shoot bola basket (Y)

2) $\mathrm{H}_{1}=0$; atau koefisien regresi variabel power tungkai $\left(\mathrm{X}_{1}\right)$, koordinasi mata-tangan $\left(\mathrm{X}_{2}\right)$, dan rasa percaya diri $\left(\mathrm{X}_{3}\right)$ signifikan terhadap variabel hasil keterampilan Lay-up Shoot bola basket (Y)

Dasar dari pengambilan keputusan adalah membandingkan $t_{\text {hitung }}$ dengan $t_{\text {tabel }}$ :

1) jika $t_{\text {hitung }}<t_{\text {tabel }}$ maka $\mathrm{H}_{1}$ ditolak, $\mathrm{H}_{0}$ diterima

2) jika $t_{\text {hitung }}>t_{\text {tabel }}$ maka $H_{1}$ diterima, $H_{0}$ ditolak

Dengan program SPSS 17.0 for windows diperoleh nilai $\mathrm{t}_{\text {hitung }}$ dan signifikansinya seperti yang terdapat pada Tabel 4.23. berikut ini:

Tabel 2

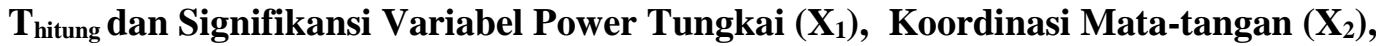
dan Rasa Percaya Diri $\left(X_{3}\right)$ Dengan Variabel Hasil Keterampilan Lay-up Shoot bola basket (Y) Coefficients ${ }^{\mathrm{a}}$

\begin{tabular}{|c|c|c|c|c|c|c|}
\hline & \multirow[b]{2}{*}{ Model } & \multicolumn{2}{|c|}{ Unstandardized Coefficients } & \multirow{2}{*}{$\begin{array}{c}\begin{array}{c}\text { Standardized } \\
\text { Coefficients }\end{array} \\
\text { Beta }\end{array}$} & \multirow[b]{2}{*}{$\mathbf{t}$} & \multirow[b]{2}{*}{ Sig. } \\
\hline & & B & Std. Error & & & \\
\hline \multirow[t]{4}{*}{1} & (Constant) & -3.876 & 6.536 & & -.593 & .561 \\
\hline & $\mathrm{X} 1$ & .578 & .134 & .581 & 4.320 & .001 \\
\hline & $\mathrm{X} 2$ & .305 & .118 & .320 & 2.582 & .020 \\
\hline & $\mathrm{X} 3$ & .191 & .141 & .189 & 1.350 & .196 \\
\hline
\end{tabular}

a. Dependent Variable: Y

Berdasarkan perhitungan SPSS 17.0 for windows, $\mathrm{t}_{\text {hitung }}$ variabel power tungkai yang diperoleh adalah sebesar 4,320 dengan df 18 pada $1 / 2 \alpha(0,05)$ dipeoleh $t_{\text {tabel }}$ sebesar 2,101, sehingga jelas $\mathrm{H}_{0}$ ditolak dan $\mathrm{H}_{1}$ diterima.

Sedangkan thitung variabel koordinasi mata-tangan yang diperoleh adalah sebesar 2,582 dengan df 18 pada $1 / 2 \alpha(0,05)$ diperoleh $\mathrm{t}_{\text {tabel }}$ sebesar 2,101, sehingga jelas $\mathrm{H}_{1}$ diterima dan $\mathrm{H}_{0}$ ditolak.

Selanjutnya thitung variabel rasa percaya diri yang diperoleh adalah sebesar 1,350 dengan df 18 pada $1 / 2 \alpha(0,05)$ dipeoleh $t_{\text {tabel }}$ sebesar 2,101, sehingga jelas $\mathrm{H}_{0}$ diterima dan $\mathrm{H}_{1}$ ditolak

Berdasarkan analisis di atas dengan bantuan komputer menggunakan perhitungan SPSS 17.0 for windows diperoleh persamaan regresi berganda sebagai berikut:

$\hat{\mathrm{Y}}=\mathrm{b}_{0}+\mathrm{b}_{1} \mathrm{X} 1+\mathrm{b}_{2} \mathrm{X}_{2}+\mathrm{b}_{3} \mathrm{X}_{3}$
$\left.\hat{Y}=-3,876+0,578) X_{1}+0,305\right) X_{2}+(0,191) X_{3}$

Konstanta sebesar $-3,876$ menyatakan bahwa jika tidak ada nilai power tungkai $\left(\mathrm{X}_{1}\right)$, koordinasi mata-tangan $\left(\mathrm{X}_{2}\right)$, dan rasa percaya diri $\left(\mathrm{X}_{3}\right)$ maka hasi keterampilan Lay-up Shoot bola basket (Y) nilainya $-3,876$ sedangkan koefisien regresi sebesar $0,578 \mathrm{X}_{1}$ menyatakan bahwa setiap penambahan 1 (satu) nilai pada variabel power tungkai $\left(\mathrm{X}_{1}\right)$ akan meningkatkan variabel hasil keterampilan Lay-up Shoot bola basket (Y) sebesar 0,578 kali pada konstanta 3,876. Koefisien regresi sebesar 0,305 $\mathrm{X}_{2}$ menyatakan bahwa setiap penambahan 1 (satu) nilai pada variabel koordinasi mata-tangan $\left(\mathrm{X}_{2}\right)$ akan meningkatkan variabel hasil keterampilan Lay-up Shoot bola basket sebesar 0,305 kali pada konstanta $-3,876$. Koefisien regresi sebesar $0,191 X_{3}$ menyatakan bahwa setiap penambahan 1 (satu) nilai pada variabel rasa percaya diri $\left(\mathrm{X}_{3}\right)$ akan meningkatkan variabel 
hasil keterampilan Lay-up Shoot bola basket sebesar 0,191 kali pada konstanta $\quad-3,876$.

Uji $F$ bertujuan untuk menguji signifikansi model regresi power tungkai $\left(\mathrm{X}_{2}\right)$ koordinasi mta-tangan $\left(\mathrm{X}_{1}\right)$, dan rasa percaya diri $\left(\mathrm{X}_{3}\right)$ terhadap hasil keterampilan Lay-up Shoot bola basket (Y). Hasil uji F seperti yang terdapat pada Tabel 4.24 sebagai berikut:

Tabel 3

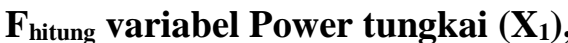
Koordinasi mata-tangan $\left(\mathbf{X}_{2}\right)$, dan Rasa Percaya Diri $\left(\mathbf{X}_{3}\right)$ Dengan Variabel Hasil Keterampilan Lay-up Shoot bola basket (Y)

\begin{tabular}{lrrrrrr}
\hline \multicolumn{7}{c}{ ANOVA $^{\mathbf{b}}$} \\
\hline Model & Sum of Squares & df & Mean Square & F & \multicolumn{1}{c}{ Sig. } \\
\hline 1 & Regression & 1536.851 & 3 & 512.284 & 23.942 & $.000^{\text {a }}$ \\
\cline { 2 - 7 } & Residual & 342.349 & 16 & 21.397 & & \\
\cline { 2 - 5 } & \multicolumn{1}{l}{ Total } & 1879.200 & 19 & & & \\
\hline
\end{tabular}

a. Predictors: (Constant), X3, X2, X1

b. Dependent Variable: Y

Uji F dilakukan untuk menguji hipotesis ini adalah;

1) $\mathrm{H}_{0}=0$; atau model regresi tidak signifikan

2) $\mathrm{H}_{1} \neq 0$; atau model regresi signifikan

Dasar pengambilan keputusan adalah :

Dengan bantuan pengolahan komputer berdasarkan perhitungan SPSS 17.0 tersebut diperoleh $\mathrm{F}_{\text {hitung }}$ sebesar 23,942 > $\mathrm{F}_{\text {tabel }} 4,381$, sehingga jelas $\mathrm{H}_{0}$ ditolak dan $\mathrm{H}_{1}$ diterima. Hal ini menunjukkan bahwa model regresi variabel power tungkai, koordinasi mata-tangan, dan rasa percaya diri sangat signifikan terhadap variabel hasil keterampilan Lay-up Shoot bola basket.

\section{SIMPULAN}

Berdasarkan deskripsi teori dan kerangka berpikir yang diajukan, maka dapat ditarik simpulan berikut : (1) Terdapat hubungan positif antara Power Tungkai $\left(\mathrm{X}_{1}\right)$ dengan hasil keterampilan Lay-up Shoot (Y) sebesar $68 \%$. (2) Terdapat hubungan positif antara koordinasi mata tangan $\left(\mathrm{X}_{2}\right)$, dengan hasil keterampilan Lay-up Shoot (Y) sebesar 42,2\%. (3) Terdapat hubungan positif antara rasa percaya diri $\left(\mathrm{X}_{3}\right)$ dengan hasil keterampilan Lay-up Shoot (Y) sebesar $47,5 \%$. (4) Terdapat hubungan positif antara power tungkai $\left(\mathrm{X}_{1}\right)$ koordinasi mata tangan $\left(\mathrm{X}_{2}\right)$ dan rasa percaya diri $\left(\mathrm{X}_{3}\right)$ secara
1) Jika $F_{\text {hitung }}<\mathrm{F}_{\text {tabel }}$ maka $\mathrm{H}_{1}$ ditolak, $\mathrm{H}_{0}$ diterima

2) Jika $F_{\text {hitung }}>F_{\text {tabel }}$ maka $\mathrm{H}_{1}$ diterima, $\mathrm{H}_{0}$ ditolak

bersama-sama terhadap hasil keterampilan Layup Shoot (Y) yang diperoleh dari koefisien korelasi R sebesar $81,8 \%$.

\section{DAFTAR RUJUKAN}

Abdullah, Arma \& Manadji, Agus. Dasardasar pendidikan Jasmani. Proyek Pembinaan dan Peningkatan Tenaga Kependidikan Direktorat Jenderal Pendidikan Tinggi Departemen Pendidikan dan Kebudayaan. (1994).

Allen, Shea. Know Yourself and the Communication Climate. [online]. Tersedia: www.allenshea.com/knowyourself.html. (2003).

Auweele, Y. Vanden., Bakker, Frank., Biddle, S., Durand, M., \& Seiler, R. Psychology for Physical Educators. Champaign, IL: Human Kinetics. (1999).

Barrow, Harold M \& Mc Gee, Rosemary, A practical Approach to Measerment In Physical Education. Lea \& Febiger. 1979.

Brown, Mike. Adventure Education and Physical Education. In: The Handbook of 
physical Education. Edit by: Kirk, D., Macdonal, D., O'Sullivan, M. London. SAGE Publications Ltd. (2006).

Bruee, Tina, Early Childhood Education, London: Hadder Stroghton. (1992).

Buchar, Charles A. Foudations of Physical Education. New York: The C.V. Mosby Company. (1979).

Corbin, et. Al., Concept in physical education: With laboratories and experiments ( $3^{\text {rd }} \mathrm{Ed}$.). Iowa: Wm. C. Brown Company Publishers. (1979).

Damon, William, \& Hart, Daniel. SelfUnderstanding in Childhood and Adolescence. New York: Cambridge University Press. (1988).

Danny Kosasih. Fundamental Basketball. Semarang : Karangturi Media. 2008

Dangsina Moeloek dan Arjatmo Tjokronegoro. Kesehatan dan Olahraga. Jakarta: Fakultas Kedokteran Universitas Indonesia 1984.

Dayakisni, T \& Hudaniah. Psikologi sosial. Malang: Universitas Muhammadiyah Malang. (2003).

Dewey, John.. Experience and Education. New York: Simon and Schuster. (1938).

Fraenkel, Jack R. \& Wallen, Norman E., How to design and evaluate research. McGrawHill, Inc. (1993).

Guntur Bernhard. Atletik. Semarang : Effhor \& Dahara Prize Offset. 1986

Harsono, Coaching Dan Aspek-aspek Psikologis Dalam Coaching. Jakarta: C.V. Tambak Kusuma. 1988.

Hergenhahn, B.R. \& Olson, Matthew H.: Theories of Learning. Pearson Education. All Right Reserved. (2008).

http://lib.uinmalang.ac.id/? $\bmod =$ th_detail \&id $=0441006$ 6

http://www.google.com/imgres?imgurl3A\%2F \%2Fibleedbasketball_jumpshot.jpg

http://www.google.com/imgres?imgurl.images $\% 2 F 40726000 \% 2 F$ Fif\%2F_40726682_jump shot_new_4.gif\&imgrefurl

http://4.bp.blogspot.com/VnPt6vVkFeM/T7JO4 djiCdI/AAAAAAAAANs/9XNcoLxOr9w/s 600/Mekanisme+Kontraksi+Otot.jpg

http://dhaenkpedro.files.wordpress.com/2008/0 9/postmus.jpg http://3.bp.blogspot.com/ e6KHJpsOmEU/TPPf YNGihI/A2MCdVqJPlQ/s320/Achilles.jpg

Hal Wissel, Bola Basket. Jakarta : PT. Raja Grafindo Persada. 1996

Imam Hidayat. Biomekanika. FPOK IKIP Bandung. 1998

Ismaryati. Tes dan Pengukuran. Surakarta : Sebelas Maret University Press. 2006.

Malim, Tony.. Social psychology. Second Edition. London: MACMILLAN PRESS LTD. (1997).

Mathews K Donalk, Measurement in Phcicak Education. London, Philedephia : Sauders company, 1985

Metzler, Michael W., Intructional Models For Physical Education. Boston. Allyn \& Bacon. (2000).

McMillan, J. H. \& Schumacher, S. Research In Education: A Conceptual Introduction. New York \& London. Longman. (2001).

Mulyono B. Tes dan Pengukuran Dalam Pendidikan Jasmani. Olaharagan Jakarta : UNS Press 2001

M. Sajoto. Pembinaan Kondisi Fisik Dalam Olahraga. Semarang : Dahara Prize 1995

Nuril Ahmad. Permainan Bola Basket. Surakarta : Era Intermedia. 2007

Pangrazi \& Dauer. Dynamic physical education for elementary school, 2nd Ed., Brown \& Benchmark Publishers Dubugue Iowa, 1992

Perbasi. Peraturan Permainan Bola Basket. Jakarta. Diterbitkan oleh Direktorat Keolahragaan, Direktorat Jendral Pendidikan Luar Sekolah, Pemuda Dan Olahraga. 2008.

Rusli Lutan. Pembaharuan Proses Agogik dan Optimalisasi fungsi Sosial Olahraga dan pendidikan Jasmani: Refleksi dalam Masa Krisis. Pidato Pengukuhan Guru Besar. Bandung. FPOK UPI. (1998).

Sarwono, S. W. Psikologi sosial individu dan teori-teori psikologi sosial. Jakarta: Balai Pustaka. (2002).

Schmidt, Ricard A. Motor Learning and Performance. Champaign : Human Kinetics Publishers Inc. 1988

Suharsimi Arikunto. Menejemen Penelitian. Jakarta : Rineka Cipta. 2007

Sudarminto. Biomekanika Olahraga I. Surakarta UNS Press. 1992 
Suharno H P. Metodologi Pelatihan, Yogyakarta: IKIP Yogyakarta Press. 1993

Veducci, Frank. Measurement concept on physical Education St Louis ; The C.V. Most By Company, 1980.

Taylor, R. L., Richards, S. B., \& Brady, M. P., Mental retardation: historical perspectives, current practices, and future directions. Boston. Allyn and Bacon. (2005).

Thomas, Jerry R. \& Nelson, Jack K. Research Methods In Physical Activity. Champaign, IL. Human Kinetick. (1996).

Tudor O Bompa, Theory and Methodology of Training The Key Athletic Performance.
Departement of Physical Education York University Canada. 1990.

Wuest \& Bucher Foundation of Physical Education And Sport. St.Louis: The C.V Mosby Company. (1995).

Widiastuti, Tes dan Pengukuran Olahraga. PT Raja Grafindo Persada. Jakarta, 2015.

Winkel. W. S. Psikologi Pengajaran. Bandung : PT. Gramedia, 1989

Kamus Besar bahasa Indonesia. Jakarta. Balai Pustaka. Departemen Pendidikan Nasional Republik Indonesia. (2015). 